\title{
STATE POWER, THE POLITICS OF DEBT AND CONFRONTING NEOLIBERAL AUTHORITARIANISM
}

\author{
CHRIS BUTLER'
}

\section{INTRODUCTION}

As an intellectual, economic, political and legal project, neoliberalism is not directed towards the rolling back of the state as an aim in itself. While its tendencies toward economic deregulation, the commodification of public services and the undermining of collective systems of social welfare superficially suggest a generalised reduction in state power in comparison to the interventionism of the Keynesian welfare state, it has been clear from the early 1980s that one of neoliberalism's primary concerns has been the reshaping of state power to engineer particular social outcomes. Contrary to the commonplace ideological presentation of neoliberalism as dependent on the return of a classical liberal nightwatchman state, state institutions have played a crucial role in securing the dominance of market rule, the privatisation of collectively owned assets and the defence of private property rights. Indeed, active interventions of the state have been an essential prerequisite for the progressive neoliberalisation of social relations in areas such as criminal justice, social welfare, systems of urban governance, the policing of organised labour and the normalisation of entrepreneurial forms of citizenship.

The contribution of the state to the rolling out and entrenchment of processes of neoliberalisation is a topic of crucial importance in an era where the subjection of social relations to the logic of the market appears to be increasingly accompanied by political and bureaucratic forms of authoritarianism. The recognition of a close relationship between neoliberalism and authoritarian forms of governance is not a new development and this phenomenon was the subject of the early critique of the rise of 'law and order' politics in the UK during the 1970s by Stuart Hall and his colleagues (Hall et al 1978). Indeed, numerous scholars have noted that, from the outset, neoliberal governance has been premised on an implicit need for the reorganisation and strengthening of state power (Bonefeld 2010a, 20I0b, 20I7; Mirowski 2009). So perhaps it is not surprising that parallel forms of aggressive neoliberal interventionism have become firmly established across numerous fields of social ordering and policy formation in the decade which has followed the financial crisis of 2008. Contemporary examples of these authoritarian tendencies in the exercise of state power include the extension and deepening of regimes of austerity in the provision of social services, public education and healthcare, the progressive weakening of democratic controls over executive decision-making and the activities of non-market institutions, and the fusing of technocratic governance with authoritarian populist policies such as the militarisation of national territory and migration (Harvey 2005, Brenner 2004; Peck and Tickell 2002; Wacquant 2009; Pugliese 2013).

\footnotetext{
I Chris Butler, Griffith Law School, Griffith University, Nathan, Queensland, Australia, 4I I I, email: c.butler@griffith.edu.au. This article is published in vol. 29(3) of Law and Critique: 3II-33I.
} 
In this article, I will consider a range of theoretical approaches which attempt to understand the role of the state within contemporary neoliberalism, and in particular the authoritarian expression of state power. I will begin by noting how the links between neoliberal economics and authoritarianism were identified even at an early stage in leftcritiques of Thatcherism and Reaganism. This has been carried through in more recent contributions by the Marxist geographer David Harvey, in his characterisation of 'accumulation by dispossession' and in Loïc Wacquant's analysis of neoliberalism as a system of marginalisation and punishment for the poor (Harvey 2005, 2006; Wacquant 2009). However, the portrayal of state authority in both writers' work is affected by a form of functionalism that limits their capacity to move beyond polemical attacks.

One important influence on studies of neoliberalism which attempt to avoid both this kind of functionalism and instrumental accounts of state power has been Michel Foucault's contribution to uncovering the historical development of neoliberalism, from its origins in German ordoliberalism, to the emergence of the Chicago School (Foucault 2008). Foucault's understanding of the production of new forms of subjectivity which extend the logic of the market across society has been crucial to Wendy Brown's assertion that neoliberalism has emerged as a dominant political rationality which undermines the possibility of democracy as a political project (Brown 2003, 2006, 2015). However, like Harvey, Brown tends to set up a dichotomy between neoliberalism and neoconservatism, which misses the inherently authoritarian character of the former.

It is in this context that I will turn to the recent work of Maurizio Lazzarato who, through readings of Foucault, Deleuze, Nietzsche and Marx, attempts to explain neoliberalism as an explicitly authoritarian imposition of the creditor-debtor relation on society (Lazzarato 2012, 2015a). Despite the utility of this approach for understanding specific examples such as the global imposition of student fees and loans, or the aggressive targeting of welfare recipients, the subsumption of the entire social field to the terrain of debt relies on a totalising ontologisation of finance capital. This leads Lazzarato to endorse a form of political voluntarism which is unable to adequately conceptualise or confront the power of the neoliberal state. Accordingly, I will conclude with some suggestions for the prospects of applying Nicos Poulantzas's concept of 'authoritarian statism' to both understanding the authoritarian character of the neoliberal state, and imagining possibilities for resisting its expressions of power (Poulantzas 2000).

\section{NEOLIBERALISM AND AUTHORITARIANISM}

It is a notoriously difficult endeavour to provide a definition of a concept such as neoliberalism which will satisfy all disciplinary, theoretical and political orientations. In this article I will treat neoliberalism as an ensemble of mutually reinforcing social, political and economic arrangements which are oriented towards the entrenchment of market relations as a dominant model for ordering human affairs, and which force individuals to assume greater personal responsibility for their well-being. The initiation and development of these tendencies has depended on both the production of new forms of subjectivity and the 
transformation of the role of the state and other forms of institutional power in governing such subjects. One of the most important aspects of this institutional embedding of neoliberalism has been its capacity to accommodate and in some circumstances specifically promote forms of authoritarianism in achieving its governance objectives. Indeed, from the outset, it is clear that neoliberal governance has been premised on an implicit need for the reorganisation and strengthening of state power (Bonefeld 2010a, 20I0b, 2017; Cristi 1998). ${ }^{2}$ This is neatly encapsulated in Andrew Gamble's early slogan for Thatcherism as 'the free economy and the strong state'. Although using the now somewhat quaint terminology of the 'New Right' in referring to the broader resurgence of right wing politics in the 1980s, Gamble neatly summarises the paradoxical character of state power under neoliberalism:

The idea of a free economy and a strong state involves a paradox. The state is to be simultaneously rolled back and rolled forward. Non-interventionist and decentralised in some areas, the state is to be highly interventionist and centralised in others. The New Right can appear by turns libertarian and authoritarian, populist and elitist. (Gamble 1994, p. 36)

Neoliberalism's authoritarian tendencies are most obviously on display within the criminal justice system, where the association between the political right and coercion has long been taken for granted. With the election of the Thatcher government in the United Kingdom and the Reagan government in the USA, it became immediately apparent that a central element of the institutionalisation of their political agenda was the dismantling of the social democratic legacy in the administration of criminal justice. Taking advantage of the exhaustion of social democratic attempts to deal with the effects of the economic crisis which ended the post-war boom in the early 1970s, the first wave of neoliberal governance launched a multi-pronged assault on all aspects of Keynesian economics and the diverse range of public sector interventions which had targeted social inequality and the failures of the free market. In the area of criminal justice policy, attempts to deal with crime by focusing on its social, economic and cultural causes were progressively displaced by the targeting of criminal offending as an individual failing, which could be combatted through intensive policing and more punitive sentencing regimes. This politicisation of law and order has assisted in reinforcing public insecurity and has utilised the mass media's predictable readiness to demand aggressive responses to crime. As an ideological project it can be understood as part of a broader historical shift towards the mobilisation of grass roots discontent through an authoritarian form of democratic politics - a project for which the late British cultural theorist Stuart Hall coined the term - 'authoritarian populism' (Hall et al 1978; Hall 1980, 1985).

This linking of neoliberalism with punitive policing and penal policies has been a consistent feature of left-sociological accounts of the criminal justice system, perhaps most prominently pursued in the work of Loïc Wacquant. Wacquant argues that the progressive, global expansion and intensification of the 'penal state' is not a contingent side-effect or a

2 For a discussion of the connection between Carl Schmitt and central intellectual figures behind the establishment of the Mont Pelerin Society see Dean (2014, Pp. I54-I55). 
'deviation from neoliberalism, but one of its constituent ingredients' (Wacquant 2009, p. 308) He sees the emergence of authoritarianism in criminal justice policy as the product not of criminal insecurity, but the social insecurity that has been produced by successive waves of neoliberalisation. The articulation of parsimonious systems of 'workfare' and the expensive public investment in 'prisonfare' (through aggressive policing, stringent sentencing guidelines and greater prison capacity) are characterised by Wacquant as the penalisation of poverty, and demonstrate the intrinsically 'illiberal' character of neoliberalism (Wacquant 2009 , pp. $312-313 ; 2010$, p. $218 ; 2014)$. This depiction of the punitive character of criminal justice policies as a response to the social insecurities produced by neoliberalism's destructive capacities is rhetorically powerful, but is hampered by a methodological functionalism, which is not able to account for the wide geographical variations between manifestations of neoliberal governance, and provides limited scope for the possibility of political contestation against such a monolithic apparatus of social management (Peck 20l0b, p. 106; Brown 201 I, p. 133).

It is also important to understand that the authoritarian tendencies of neoliberalism extend beyond the more obvious examples of the punitive turn in the criminal justice system, the militarisation of border protection regimes or the war on terror. Such tendencies stem from the neoliberal drive to reshape state power in order to engineer particular social outcomes, which is also manifest in areas such as the creation, ex nihilo, of markets for public goods, the disciplining of organised labour, ongoing attacks on social provision and the intensification of austerity. Each of these instances challenge the simplistic assumption that neoliberalism is an inherently anti-statist programme, primarily focused on freeing individual citizens and the economy from unnecessary state interference. These broader links between the neoliberal state and authoritarianism across a range of social fields have become widely recognised within the Marxist political economy tradition. Perhaps the most well-known account within this school of thought is David Harvey's characterisation of neoliberalism as an extension of the practices and strategies of accumulation that Marx depicted as 'primitive' during the emergence of capitalism as an economic system (Harvey 2006, p. 153). In doing so, he draws on a number of the writings of the Midnight Notes Collective which sparked renewed debate about the ongoing nature of processes of enclosure and their consequent destruction of spaces and resources held in common (Midnight Notes Collective 1990; De Angelis 200I).

For Harvey, neoliberalism is a brutal restoration of ruling class power, through which the state plays a central and coercive role in promoting a range of social mechanisms, including the privatisation of land and property rights, the financialisation of social life, the commodification of labour and the suppression of rights to the common, which he collectively refers to as 'accumulation by dispossession' (Harvey 2003: chapter 4; 2005; 2006). But despite the violence inherent in such governance processes, Harvey is never entirely clear in his explanation of what drives the authoritarian tendencies of the neoliberal state, which at times he seems to characterise as aberrations, which contradict the ideological presentation of neoliberalism. 
[T] he neoliberal state will resort to coercive legislation and policing tactics ... to disperse or repress collective forms of opposition to corporate power. ... The coercive arm of the state is augmented to protect corporate interests and, if necessary to repress dissent. None of this seems consistent with neoliberal theory. (Harvey 2005, p. 77)

Indeed Harvey attributes the coercive manifestations of neoliberal state power to an ideological shift to a loosely defined tendency towards 'neoconservatism', which has arisen as a functional response to the contradictions of neoliberalism as a political project, and its instability as a mode of governance (Harvey 2005, pp. 8I-82, 195). On this account, state coercion is an exception, which provides a temporary solution for the problems of maintaining social order and moral cohesion that neoliberalism exacerbates. For Wacquant, Harvey's discussion of the neoliberal state is fatally compromised by an instrumentalistrepressive understanding of power which restricts the latter's capacity to understand the centrality of penal institutions to the operations of the neoliberal state. He argues that Harvey introduces an unhelpful dichotomy between neoliberalism and neoconservatism, which derives from a 'narrow economistic' reading of neoliberal power which 'replicates its ideology and truncates its sociology' (Wacquant 2010, pp. 215-216). While Wacquant is correct to point out the way in which Harvey avoids confronting the intrinsically authoritarian character of neoliberalism, his own account is also restricted by an inability to extend its explanatory method beyond a focus on the penalisation of poverty.

\section{GOVERNMENTALITY AND NEOLIBERAL RATIONALITY}

In contrast to these instrumentalist and functionalist accounts of neoliberal authority, an important strand of recent writing has focused on neoliberalism's dependence on the production of new forms of subjectivity, and the transformation of the forms of institutional power which govern such subjects. The most important influence on the development of this theoretical orientation has been Michel Foucault's late lectures on governmentality. Particularly in The Birth of Biopolitics, Foucault depicts the historical transformations of liberal thought via the prominent perspectives within German ordoliberalism (from the late 1930s and during the immediate postwar period) and the development of American neoliberalism during the 1960s and 1970s (Foucault 2008). Drawing on the theory of 'human capital' developed in the work of the Chicago School economist Gary Becker, Foucault argues that neoliberalism is premised on a reformulation of homo oeconomicus, but not as envisaged in classical liberalism as a 'partner of exchange' who can be analysed in terms of a 'theory of utility based on a problematic of needs' (Foucault 2008, p. 225). The neoliberal version of homo oeconomicus is presented as 'an entrepreneur of himself [sic], and a consistent strand which links the projects of ordoliberalism and neoliberalism is the transformation of individuals into a type of 'enterprise' engaged in the production of personal satisfaction (Foucault 2008, p. 226). In shifting the focus from individuals or socio-economic processes to enterprises, neoliberal thought extends this basic economic logic by rationalising it throughout society (Foucault 2008, p. 225). Foucault finds in the American neoliberals the 
most radical expression of this generalisation of the "'enterprise" form within the social body or social fabric', which involves 'taking this social fabric and arranging things so that it can be broken down, subdivided, and reduced, not according to the grain of individuals, but according to the grain of enterprises' (Foucault 2008, p. 24I).

Jason Read argues that this extension of the enterprise form throughout society means that many areas of everyday life which have not historically been 'conducted' or valued through 'monetary exchanges' become subjected to the 'symbols, terms' and competitive logic of capitalism (Foucault 2008, p. 243; Read 2009, p. 32). Accordingly, neoliberalism amounts to a new mode of 'governmentality' through which 'people are governed and govern themselves' (Read 2009, p. 29). Contrary to Marx's insistence on the economic determination of social and political relations through processes of production, Read describes Foucault's account of the 'politics of neoliberalism' in the following terms:

The opposition between capitalist and worker has been effaced not by a transformation of the mode of production, a new organization of the production and distribution of wealth, but by the mode of subjection, a new production of subjectivity. Thus, neoliberalism entails a very specific extension of the economy across all of society; (which) is not, as Marx argued, because everything rests on an economic base ..., rather it is an economic perspective, that of the market, that becomes coextensive with all of society. (Read 2009, p. 32, italics in original)

In Foucault's account, this generalisation of the enterprise form and its production of a new mode of subjectivity through homo oeconomicus cannot succeed without the active interventions of the state. Much of his close historical study of the emergence of the discourse of neoliberalism is concerned with the important role attributed to state intervention within the work of ordoliberal writers such as Alexander Rüstow and Wilhelm Röpke, and other prominent influences on the emergence of American neoliberalism, such as Friedrich Hayek. In rejecting the 'naïve naturalism' of laissez-faire, the emerging neoliberal intellectual movement recognised the necessity for the free market and the extension of the preconditions for liberal society to be positively created and reinforced by the state. In Foucault's words, 'Neoliberalism should not therefore be identified with "laissez-faire", but rather with permanent vigilance, activity, and intervention' on the part of state institutions (Foucault 2008, p. 132).

This requirement for the market and rational competitive human behaviour to be actively constructed, organised and politically implemented leads Wendy Brown to argue that the emergence of homo oeconomicus transforms the way in which governmental power can operate under neoliberalism (Brown 2015, p. 57). In her work, one of the most productive aspects of Foucault's account is its attention to a new governing rationality which demands the submission of, not just politics, but all aspects of contemporary life to an economic calculus.

Importantly then, neo-liberalism involves a normative rather than ontological claim about the pervasiveness of economic rationality and advocates the institution building, policies, and discourse development appropriate to such a claim. Neo-liberalism is a 
constructivist project: it does not presume the ontological givenness of a thoroughgoing economic rationality for all domains of society but rather takes as its task the development, dissemination, and institutionalisation of such a rationality (Brown 2003).

For Brown, this dominant political rationality, powered by a modality of homo oeconomicus as human capital, has had profoundly 'de-democratising' effects, as homo politicus is effectively neutered as the basis for active forms of political citizenship, and notions of 'the public good, rights and debate' no longer have any meaningful impact (Read 2009, p. 35; Brown 2006). The unchallenged dominance of 'neoliberal reason' and its submission of all aspects of life to economic valuation not only restricts the possibilities for 'common investment in public life and public goods', it remakes the state 'from one founded in juridical sovereignty to one modeled on a firm' and dramatically transforms the 'citizensubject from a political to an economic being' (Brown 20I5, p. 108). This generates a profound depoliticisation of social relations which jeopardises the very idea of democracy as a political project. While individual policies which undermine social solidarity or privatise collectively owned infrastructure may be rolled back, without a serious challenge to neoliberal political rationality, democracy will continue to be undermined (Brown 20I5, p. 20I).

It is through the damage wrought to liberal democratic institutions by neoliberalism that Brown attempts to make sense of the rise of right-wing authoritarianism in the political systems of the United States and certain parts of Europe in recent years. In an earlier formulation of this argument, Brown suggested that the rise of statism and authoritarianism has been the consequence of a coalescence of neoliberal and neoconservative rationalities. While accepting that these two rationalities appear to pursue contradictory trajectories, it is neoliberalism's hostility to democratic institutions and practice, and its treatment of politics as a potential threat to freedom and the effective operation of markets, which lead it to accommodate a form of statism which has prepared 'the ground for the authoritarian features of neoconservative governance' (Brown 2006, p. 705). Speaking recently about the political context which led to the presidential election of Donald Trump, Brown highlights the role of neoliberal political rationality in facilitating the rise of what she describes as 'apocalyptic populism'

the open neoliberal disparagement of politics; the assault on democratic institutions, values and imaginaries; the neoliberal attack on public goods, public life, social justice and an educated citizenry generate a novel anti-democratic, anti-egalitarian, libertarian, authoritarian political formation. (Brown 2017)

Although Brown is clearly realistic about the limitations of liberal democracy, a number of commentators have noted her melancholic tone as she laments its decline, and her underlying pessimism about the prospects of challenging neoliberal rationality and its stranglehold over institutions and their de-democratised subjects (Gane 2016, p. 354; Dean 2016). As Jodi Dean points out, Brown takes for granted a linear path of political emancipation, from bourgeois democracy to more substantive and radical democratic 
instantiations' (Dean 2016, p. 982). Once liberal democracy has been trashed, the very possibility of establishing alternative democratic forms has been extinguished. Importantly, Brown is not prepared to acknowledge an inherent association between neoliberalism and authoritarianism, and in this sense reproduces a similar distinction to that made by Harvey, in attributing the authoritarian tendencies of the contemporary neoliberal state to its 'enabling' of neoconservatism (Brown 2006, p. 702). While Brown is correct to point out that the early neoliberal theorists did not condone the ethnonationalist or plutocratic tendencies that currently appear to be resurgent, her claim that 'neoliberalism was not inherently ... authoritarian' runs counter to a number of accounts of the historical origins of neoliberal thought (Brown 2017). ${ }^{3}$

\section{DEBT AND SUBJECTIVITY UNDER NEOLIBERALISM}

Recently, Maurizio Lazzarato has sought to build on Foucault's insights on the neoliberal production of entrepreneurial subjectivity, by binding them to a more thoroughgoing account of the authoritarian character of contemporary state power than Brown's account can provide. In a series of interventions published in the decade following the financial crisis of 2007-2008, Lazzarato has focused on the role of debt in intensifying and extending mechanisms of exploitation and domination across all levels of society (Lazzarato 2012; $2015 \mathrm{a} ; 2017)$. A central theme in these works is an attempt to rethink the creditor-debtor relation as constituting the 'subjective paradigm of modern-day capitalism' (Lazzarato 2012, p. 38). Structuring his argument through a theoretical matrix mapped out by Deleuze and Guattari's Anti-Oedipus, Nietzsche's On the Genealogy of Morality and Marx's theory of money, Lazzarato posits the creditor-debtor relation as

itself a power relation, one of the most important and universal of modern-day capitalism. Credit or debt and their creditor-debtor relationship constitute specific relations of power that entail specific forms of production and control of subjectivity a particular form of homo economicus, the 'indebted man' [sic]. (Lazzarato 20I2, p. 30)

Lazzarato argues that Foucault's reflections on neoliberal thought in The Birth of Biopolitics fail to adequately consider the role that finance and debt play as 'strategic mechanisms of neoliberal government' from the late 1970s onwards (Lazzarato 2012, p. 90). While he acknowledges that understanding the individual as being transformed into a form of complex enterprise is crucial, Lazzarato is convinced that this now occurs within the context of a debt economy which is very different from the 'industrial' version of postwar neoliberalism to which Foucault's account remains wedded (Lazzarato 2012, p. 91). By contrast with the postwar ordoliberal objective to use state policy to 'deproletarianise' the population through reducing the size of production units and facilitating worker comanagement and share ownership schemes, contemporary neoliberalism articulates deproletarianisation in discursive terms alone. Through wage stagnation and austerity

3 For discussions of the crucial role that an acceptance of authoritarianism has played in the development of neoliberal thought, see: Peck (2010a, chapter I); Mirowski (2009, p. 44I); Bonefeld (20I0a, 20I0b, 20I7); Dean (20I4); Cristi (1984, p.199); Scheuerman (199); Hayek (1960, p. 217, 1966). 
policies the situation of the entrepreneurial subject within the debt economy 'has been transformed into its opposite ... economic and existential precariousness, which is but the new name for the old reality: proletarianization' (Lazzrato 2012, p. 93).

An important influence on Lazzarato's critical evaluation of Foucault in this respect is Deleuze's positioning of debt as a central element in the shift from a disciplinary model of governance to a 'society of control' (Deleuze 1992). Unlike the operational environments of enclosure that commonly define disciplinary societies (such as schools, hospitals and factories), Deleuze claims we are no longer enclosed, but our social existence is defined by debt: 'Man [sic] is no longer enclosed, but man in debt' (Deleuze 1992, p. 6; Lazzarato 2012, p. 90; 2015a, p. 92). In doing so, Deleuze appears to assume that control societies are 'succeeding' disciplinary societies, which leads to an exaggerated emphasis on a dramatic transition from mechanisms of discipline to those of control. As William Davies argues, it is more accurate to note the layering of techniques of control upon those of discipline, rather than suggesting the replacement of one by the other (Davies 2015, p. 46). Similarly, Lazzarato understands neoliberal forms of governmentality as relying upon the continued coexistence and simultaneous deployment of 'sovereign, disciplinary and security techniques' (Lazzarato 2015a, p. 21 I).

Nevertheless, Lazzarato enthusiastically follows the work of Deleuze, particularly the latter's collaboration with Guattari in Anti-Oedipus, in identifying Nietzsche's discussion of the close relationship between the 'material' concept of debt and the 'moral' concept of guilt as a crucial resource for characterising the subjectivity of the indebted individual (Deleuze and Guattari 1983). In the second essay of On the Genealogy of Morality, Nietzsche explores not only the inherent connection between the creditor-debtor relation and legal subjectivity, but the necessary cruelty which underlies this relation:

The debtor, in order to inspire confidence that the promise of repayment will be honoured, in order to give a guarantee of the solemnity and sanctity of his promise, and in order to etch the duty and obligation of repayment into his conscience, pawns something to the creditor by means of the contract in case he does not pay, something that he still 'possesses' and controls, for example, his body, or his wife, or his freedom, or his life ... [T] he creditor could inflict all kinds of dishonour and torture on the body of the debtor, for example, cutting as much flesh off as seemed appropriate for the debt: ... there were everywhere, early on, estimates which went into horrifyingly minute and fastidious detail, legally drawn up estimates for individual limbs and parts of the body. (Nietzsche 2006, pp. 40-4I)

Echoing the Deleuzoguattarian affirmation of this account of debt, Lazzarato describes the creditor-debtor relationship as the contemporary 'archetype of social relations' and as morally producing a mode of subjectivity which is premised on 'work on the self; an 'ethico-political labor constitutive of the subject' (Lazzarato 2012, p. 33, 42; Muldoon 2014, p. 68). Through our promises to honour our debts into the future, we are all transformed into indebted economic and political subjects whose tendencies towards potentially unpredictable or insurrectionary behaviour are kept under control. Accordingly, 
the neoliberal debt economy expands through a dual 'exploitation of subjectivity', both 'extensively' (through infiltrating the entire corpus of social activities), and 'intensively' by incorporating

the relationship to the self, in the guise of the entrepreneur of the self - who is at once responsible for 'his' [sic] capital and guilty of poor management - whose paradigm is the 'unemployed'. (Lazzarato 2012, p 52)

A demonstration of this intimate association between debt and guilt can be observed in the recent controversy over the implementation of an automated debt recovery system by the Australian Department of Human Services. Promoted by the Government on its introduction in late 2016, the 'Online Compliance Intervention' $(\mathrm{OCl})$ system was projected to raise $\$ 2.1$ billion by 2020 , by eliminating welfare fraud and recouping overpayments of benefits (Morrison and Cormann 2016, p. 24). In practice, the $\mathrm{OCl}$ raised less than a quarter of the projected revenue during its first year of operation, but has generated thousands of incorrect debt notices to 'customers' who have been identified as owing debts for past overpayments of unemployment benefits. The Department of Human Services has been subjected to widespread criticism from activists in the welfare sector, commentators and legal academics for the system's multiple design flaws and the aggressive way it has dealt with the process of debt collection (ACOSS 2017; Carney 2018; Hanks 2017). While the Department had been using manual processes of cross-matching of declared income and taxation records since the early 2000s, the $\mathrm{OCl}$ system has removed previously necessary stages of human oversight, which ensured that an average of only seven percent of data discrepancies were pursued as formal debts. The new algorithms used by the OCl's 'robodebt' system average out yearly income into fortnightly amounts and effectively generate false discrepancies in any case where a person's pay, employment or training circumstances have varied throughout the year. These design flaws and the removal of stages of datachecking has allowed for a massive increase in debt notifications sent to welfare recipients of up to 20,000 per week. This can be compared with around the same number of notifications annually, when the previous manual system of checking discrepancies was in operation.

The $\mathrm{OCl}$ system has effectively shifted the onus of proof of establishing whether a 'debt' actually exists, or whether the amount alleged is accurate, to the person who is notified of the 'debt', who then has the obligation to pay the debt, challenge its existence or dispute the amount which is owed. This is a very serious issue for the individuals involved because the inaccurate data used by the $\mathrm{OCl}$ algorithms has often either falsely generated debts, or grossly inflated the amounts of money alleged to be owed. In testimony before the Senate Committee Inquiry into the $\mathrm{OCl}$ system, the Department's Secretary acknowledged that in 'approximately 20 per cent of cases where an individual has received an initial letter identifying a discrepancy' between [income and taxation records], the debt had been cancelled after they provided information clarifying their circumstances (Senate Community Affairs References Committee 2017, Pp. 32-33; McKinnon 2017). Questions have been raised about the legality of this shifting of the onus of proof onto welfare recipients and the 
state's avoidance of its responsibility to prove the existence and size of a debt, given that there is no provision under the Social Security Act 199I (Cth) which authorises the creation of a debt solely on the basis of a discrepancy revealed by data-matching technology, without further investigation (Carney 2018, p. 6). The robo-debt system provides a real-time demonstration of how neoliberal governance has aggressively harnessed emerging forms of digital technology and the management of large data sets to implement reductions in public sector staffing, and retrospectively impose responsibilities on welfare consumers in the name of austerity (Galloway 2017; Desai and Kroll 2017; Coglianese and Lehr 2017). Most importantly for the discussion here, the shift in the onus of proof that is built into the system reveals the use of these technologies to administratively assign guilt for the provision of past welfare benefits as a reminder to the recipient that they will perpetually remain in the public's debt.

\section{NEOLIBERALISM AS STATE CAPITALISM}

Australia's robo-debt compliance machinery and the global financialisation of higher education, which forces students to enter the labour market with crushing personal indebtedness are good examples of Lazzarato's argument that the 'right to contract debt' has replaced previously universal social rights (Lazzarato 20I5a, p. 66). Nevertheless, it is appropriate at this point to ask whether the concept of debt can sustain the weight which Lazzarato attaches to it as an archetype of contemporary neoliberal subjectivity. He argues that the subjective and moral dimensions of the contemporary debt economy, and its inherently 'asymmetrical' violence suggest that, in order to adequately comprehend the authoritarian dimensions of state power under neoliberalism, it is necessary to radically adjust our understanding of the 'genealogy of social relations and institutions'.

The asymmetry of power constitutive of debt rids us of the 'dream' according to which the State and society begin with a contract (or, in the updated version, a convention). ... The processes constitutive of society do not involve progressive changes, consent, agreement, or delegation, but 'ruptures', 'leaps', and 'constraints' ... If more proof of this state of affairs were needed, one need only look at how neoliberalism has imposed itself. Surely not by contract or agreement, but by theft, violence, and usurpation. (Lazzarato 2012, pp. 43-44)

It is around this question of how to best face up to the authoritarian character of the neoliberal state that Lazzarato identifies a second limitation in Foucault's discussion of governmentality in The Birth of Biopolitics. By framing the historical conditions of liberalism in terms of 'freedom' and the resolution of the problem of 'governing too much', Lazzarato accuses Foucault, perhaps unfairly, of a 'certain political naiveté', by failing to recognise that the "parable of "liberalism" ... always ... leads to, the same thing: crisis, limitations on democracy and "liberal" freedoms, and the institution of more or less authoritarian regimes' (Lazzarato 2012, PP. 108-109; Foucault 2008, PP. 319-322). ${ }^{4}$ In exploring this

${ }^{4}$ I am indebted to Daniel McLoughlin for pointing out the extent to which Lazzarato over-extends his critique of Foucault in this regard: McLoughlin (2017). 
characterisation of the authoritarian dimensions of state power under neoliberalism, Lazzarato draws on Carl Schmitt's reflections on the meanings of nomos in the Appendix to his Nomos of the Earth (Schmitt 2006). For Schmitt, every political, legal, social and economic order is structured by three principles, which correspond to three meanings of the word nomos: appropriation, distribution and production (Schmitt 2006, pp. 324-335).

Each of these three processes - appropriation, distribution, and production - is part and parcel of the history of legal and social orders. ... Prior to every legal, economic, and social order, prior to every legal, economic, or social theory are these elementary questions: Where and how was it appropriated? Where and how was it divided? Where and how was it produced? (Schmitt 2006, pp. 327-328, italics in original)

In his more recent work, Governing by Debt, Lazzarato draws on Schmitt's identification of the reorganisation of the existing rules governing appropriation, expropriation and ownership of property as logically prior to its allotment and distribution and the emergence of any new system of production (Lazzarato 2015a, p. 54). So while it is possible to identify a new model of distribution in the postwar Keynesian welfare state, it is crucial to also understand it as a new 'ownership regime' for social resources, which required taking wealth from some groups and transferring it to others. With this in mind, Lazzarato argues that the state's response to the 2008 financial crisis demonstrates very clearly the juridico-political imperatives of neoliberalism:

What liberals have had their sights on during the crisis is not a minimum state but a state freed from class struggle, from the pressure of social demands, and from the threat of expanding social rights. The debt crisis has clearly shown that the social state itself is at stake in appropriation, distribution, and production. The objective is not balanced budgets. The struggle has to do with the three concepts of nomos: 'who' appropriates, 'who' distributes, 'who' utilizes social plunder. The debt crisis is the political battle for the definitive seizure of the welfare state by neoliberal forces. (Lazzarato 20I5a, p. 56)

Contrasting with the use of Schmitt's critique of liberalism by members of the Italian operaismo movement such as Mario Tronti in the 1960s and 1970s, who argued for the 'autonomy of the political', Lazzarato is more interested in how Schmitt helps us understand the emergence of the Keynesian 'social state' as a crucial moment in the undermining of the political autonomy of the state (Tronti 1977; Lazzarato 20I5b, p. 70). The state is constantly 'traversed' by the social and economic demands of capital and is accordingly the site of class conflict and an ongoing 'civil war' over the appropriation and distribution of the 'spoils' of social wealth and the allocation of debt (Lazzarato 20I5a, Pp. 5I-52). For Lazzarato this civil war has heightened since the emergence of neoliberalism, and on his analysis, the debt crisis is not only economic in origin, or primarily driven by market failure, but is also a political failure of neoliberal governance, which reveals the disintegration of the existing 'political relationship between appropriation, distribution, and production' (Lazzarato 2012, PP. 109; 20I5a, p. 56). 
The extent to which the state is overwhelmingly dominated by political and economic struggles provides an opportunity for Lazzarato to reiterate the ongoing validity of Deleuze and Guattari's characterisation of the relationship between state and capital. Far from liberalism providing a theoretical and practical buffer between state and capital which defends social and economic freedoms, Deleuze argues that capitalism 'has never been liberal; it has always been state capitalism' (Lazzarato 20I5a, p. 92; Deleuze 197I). Indeed liberal struggles against the privileges of monopoly in an earlier era do not 'imply any struggle against the very principle of State control' (Deleuze and Guattari 1983, p. 253). Lazzarato identifies in this formulation a way of understanding neoliberalism as simply the most recent phase in the articulation of 'capital and the state, of sovereignty and the market' (Lazzarato 2015a, p. 94). The contemporary politics of austerity and cuts to public services, along with the enforcement of wage restrictions and attacks on organised labour are all aspects of the neoliberal programme of subordinating administration and social relations to the logic of 'capitalist valorisation' (Lazzarato 2015a, p. 102). This 'constitution and extension' of state capitalism does not involve a minimal state, conscious of the dangers of 'governing too much', but an abandonment of all attempts to produce 'freedom' in favour of the production of 'post-democratic authoritarian governmentality' (Lazzarato 20I5a, p. II2, 129).

The integration of the state and the market, of sovereignty and governmentality, of politics and the economy, of society and capital, has been pushed still further by exploiting the 'shock' of the financial collapse. The liberal managers of the crisis have not hesitated to include a 'maximum state' among the apparatuses of governmentality but a state that now exercises its sovereignty uniquely on the population. To free up the markets, liberal management imprisons society, intervening in heavy-handed, invasive and authoritarian ways in the life of the population in an effort to govern all aspects of behavior. (Lazzarato 2015a, PP. 129-130)

In some respects, Lazzarato's writings on debt appear to display a 'turn' from his previous preoccupations with the vitalist philosophies of Bergson and Tarde towards a rhetorical rapprochement with classical Marxist critiques of the state form (Lazzarato 2002; 2004; 2007; Toscano 2007; Muldoon 2014). However his adoption of the Deleuzian formulation of 'state capitalism' generates a weakness in his account of neoliberal power. Central to his methodology is an attempt to move beyond the 'critique of political economy' by employing a 'non-economistic theory of the economy', which subsumes subjectivity, desire, morality and discourse into a generalised theory of production (Lazzarato 2012, p. 42, 72). But, as Alberto Toscano argues, Lazzarato's position here is driven by an 'ontologisation' of capital, which neglects its 'historical limits and specificities ... spreading it all the way up and all the way down' (Toscano 2014). By collapsing the distinction between state power and the power of capital, Lazzarato claims that capitalist power is defined by its capacity to determine the social meaning of the possible and the impossible. Invoking Thatcher's famous slogan for the inevitability of capitalism, he claims, the 'first watchword of neoliberalism has been "there is no alternative", in other words, there are no other 
possibles than those proclaimed by the market and finance' (Lazzarato 2015a, p. 23). This ontological conflation of state and capital through the figure of state capitalism, limits Lazzarato's capacity to adequately account for the ways in which the exercise of state power is driven by the imperatives of non-financial fractions of capital, or responds to the political demands of social movements and groups within civil society - neither of which have been extinguished by the rise of the debt economy, and both still exercise political impacts on regulatory processes within the state. By positing the dominance of capital's imperatives within and through the state in this way, Lazzarato almost entirely reduces the authoritarian character of neoliberalism to a product of the totalising forces of financial capital.

\section{CONFRONTING NEOLIBERAL AUTHORITARIANISM}

A second consequence of Lazzarato's reading of capital in ontological terms is a tendency towards a form of political voluntarism, which attempts to strategically bypass the nationstate, but ends up failing to take the complexity of neoliberal authority seriously, and thereby compromises its own attempts to contest it (Toscano 2014). Lazzarato may be correct to identify the 'impossibility of reform' in the terms envisaged by neo-Keynesians as an imaginary 'new New Deal', but it is nevertheless the case

that contemporary struggles about debt are struggles in and against the state (at a variety of levels, from local authorities to central banks). It is self-defeating to imagine that we get to choose the terrain of our struggles; the conjuncture of sovereign debt crises, austerity, workfare and the refunctioning of the 'social' as an instrument of discipline and dispossession means that the state is indeed a crucial component of that terrain - which need not imply any nostalgia for the post-war boom and its social compact. (Toscano 20|4)

Lazzarato's own suggestions for politically confronting neoliberalism depend upon strategies which can reinvigorate and reframe class struggle under circumstances that have shifted to the "“deterritorialised" ground of debt', which traverses all social, economic and political domains (Lazzarato 2012, p. 16I). On his analysis, the task for those challenging the imposition of neoliberal authority requires the invention of 'new forms of subjectivation and new possibilities of life' which may potentially break the stranglehold of the 'morality of guilt' of the debt economy (Lazzarato 2012, pp. 163-164). Fleshing out this idea further in Governing by Debt, Lazzarato returns to a familiar concept within the traditions of operaismo and autonomia - that of the 'refusal of work' (Lazzarato 20I5a, Pp. 245-255; Tronti 1965; Thoburn 2003). Lazzarato identifies the effectiveness of workers' strikes during the period of industrial capitalism as residing in their ability to immobilise production and block the 'valorization of capital'. Accordingly, he proposes a recuperation of Paul Lafargue's polemical demand for the 'right to be lazy' as an analogous form of resistance against contemporary forms of imposed subjectivity, and our 'assignations' within the social division of labour (Lazzarato 20I5a, p. 247; Lafargue 20II). 
Drawing inspiration from Marcel Duchamp's rejection of the 'artist's integration into the capitalist economy and the transformation of art into a commodity', Lazzarato conceives of the refusal of work as an 'ethical-political principle that goes beyond work, which frees us from the enchanted circle of production, productivity, and producers' (Lazzarato 20I4, p. 6). ${ }^{5}$ This bold rejection of those techniques of governmentality which generate forms of social subjection though the norms of individualised 'human capital', the practices of consumerism or the moral disgrace associated with welfare debt certainly has radical political appeal. But ultimately, such a strategic orientation fails to confront the residual, institutional violence of state power under neoliberalism, which embodies logics extending beyond the asymmetrical violence of the debt relation. A crucial requirement of any emancipatory confrontation with neoliberalism is the combination of extra-institutional politics of refusal with attempts to transform and supplant existing state institutions (Fisher and Gilbert, p. 96).

In this context, it is worthwhile considering the contribution of the late writings of Nicos Poulantzas to an understanding of the authoritarian tendencies of the contemporary neoliberal state, in order to think through the possibilities for radically contesting them. In his final book State, Power, Socialism (published in 1978), Poulantzas argues that 'political domination' is 'inscribed in the institutional materiality of the State', rather than being the result of the instrumental use of the state apparatus by the class agents of capital (Poulantzas 2000, p. 14; Jessop 1980, Pp. 109-110). Partly drawing on Foucault's relational theory of power, Poulantzas depicts state power as an expression of a 'specific material condensation of a relationship of forces' between social groups - or in other words - the product of political struggles (Poulantzas 2000, Pp. 128-129). An implication of this approach is that oppositional political movements must simultaneously develop popular democratic networks at a remove from state institutions, while also seeking to intervene within those institutions to transform their material basis (Poulantzas 2000, pp. 259-265). The focus of Poulantzas's analysis in this work is on the transformation of Keynesian social democratic institutions during the 1970s into a new state form, which he introduces through the concept of 'authoritarian statism', defined as:

intensified state control over every sphere of socio-economic life combined with radical decline of the institutions of political democracy and with draconian and multiform curtailment of so-called 'formal' liberties. (Poulantzas 2000, Pp. 203-204, italics in original)

Poulantzas was not alone in identifying these tendencies in the late Keynesian state, but he sought to distinguish his own position from the exaggerated perspectives associated with the Frankfurt School and some traditions of the New Left in the United States, by insisting that authoritarian statism should not be conflated with totalitarianism or

\footnotetext{
5 Lazzarato also invokes Duchamp's radical politics of creativity (which rejects the idea of art as a professional specialisation) in his study of the French intermittents (casualised cultural workers) in their struggles against neoliberal austerity measures restricting their access to unemployment insurance: see Lazzarato (20|7).
} 
understood as a variant of fascism (Poulantzas 2000, p. 205). ${ }^{6}$ In State, Power, Socialism, Poulantzas argues that it should be understood as the emergence of a new form of 'democratic' state in response to both the economic crisis of the mid-1970s and political resistance to capital's attempts to resolve that crisis. In institutional terms, authoritarian statism is characterised by a blurring of the distinction between the three arms of government and a devaluing of the rule of law; the transfer of crucial areas of decisionmaking from the legislature to the executive (concentrating power in the latter); and a practical decline in the effectiveness of parliament as a forum for political representation (Poulantzas 2000, p. 217; Jessop 201 I, p. 48).

It is obvious that this account of authoritarian statism cannot be mechanically applied to an analysis of the neoliberal state, and even writers sympathetic to Poulantzas's work have emphasised how his analysis failed to predict a number of crucial characteristics of the contemporary political conjuncture (Jessop 201I; Demirović 20II; Kalyvas 2002). For example State, Power, Socialism does not envisage the changing dynamics between capital and organised labour in the global shift to a post-Fordist regime of accumulation, which paved the way for the neoliberal turn. In addition, Poulantzas did not adequately incorporate an understanding of ways in which state institutions 'have been re-scaled upwards, downwards, and sideways' to manage the complexities of the world economy, and have transformed state power 'from top-down planning and hierarchical rule towards decentralized contextsteering and other forms of governance in the shadow of hierarchy' (Jessop 201 I, PP. 5354). Nevertheless, Poulantzas was quite prescient in identifying a number of aspects of authoritarian statism which have continued relevance for contemporary political and legal developments in advanced industrialised countries, including the dysfunctional nature of parliamentary institutions as an avenue of political debate and the growth and autonomy of executive power, alongside increasing restrictions on the judicial review of executive decision-making.

In recent years, the lens of authoritarian statism has been adopted by an increasing number of researchers working within the fields of law, politics and state theory, including a group of scholars associated with the concept of 'authoritarian neoliberalism', who advance an 'explicitly "political” reading of neoliberalism' over economically determinist or 'ideational' explanations (Bruff and Tansel 2018; Bruff 2014, 2016; Tansel 2017). In a seminal article, lan Bruff describes the emergence in Europe during the last decade of a new version of neoliberalism which is based less on consent for a political programme portrayed as 'socially desirable' or 'economically efficient', and increasingly relies upon constitutional and legal mechanisms to 'insulate certain policies from social and political dissent' (Bruff 2014, p. II5). In studying these developments, Bruff argues that we should understand the state as a

\footnotetext{
6 In a brief footnote, Poulantzas acknowledges some commonalities between his position and Henri Lefebvre's account of the 'state mode of production' (Poulantzas 2000, p. 50). Lefebvre argues that the state plays an active role in simultaneously fragmenting, homogenising and hierarchically ordering socio-spatial relations; a process he describes as the production of 'abstract space' (Lefebvre 1977, 200I, 2003; Butler 2012, pp. 98-99). While it is not possible to pursue the links between these thinkers in any further detail here, see the discussion in Brenner (200I).
} 
permanent and necessary part of neoliberal ideology, institutionalization and practice. For it is state-directed coercion insulated from democratic pressures that is central to the creation and maintenance of a politico-economic order which actively defends itself against impulses towards greater equality and democratization. (Bruff 2016, Pp. 109- I I0, italics in original)

It is possible to criticise some of the writing on authoritarian neoliberalism for proposing a clear historical periodisation which detaches current neoliberal practices and modes of governance from those in operation during the years preceding 2007 (Ryan 2017). However, Poulantzas's concept of authoritarian statism has been used by other writers to explain how contemporary forms of state authority have inherited many of the statist characteristics of late Keynesianism and adapted them to new uses. One example of this can be seen in Ntina Tzouvala's explanation of the aggressive attacks on organised labour by the neoliberal state in Greece (Tzouvala 2017, Pp. 133-134). A second instance is the detailed defence of authoritarian statism by Christos Boukalas to understand the militarisation of national security and pre-emptive policing, particularly through the development of counterterrorism and homeland security policies in the United States (Boukalas 20l4). Boukalas argues that a common thread linking the transition from the crisis of the Keynesian welfare state during the late 1970s to a neoliberal workfare state of the 1980s and beyond is the entrenchment of authoritarian statism. ${ }^{7}$

Perhaps most importantly, Poulantzas's understanding of the tensions inherent in authoritarian statism provides us with ways of thinking about how to contest the assumed dominance of the neoliberal state. By restricting dissent, and heightening levels of coercion and violence, the state raises the stakes, undermines its legitimacy and opens itself up to new forms of resistance and challenge. Poulantzas describes this as a tendency towards the 'strengthening-weakening of the state', which is partially responsible for generating new forms of popular struggle and direct challenges to the imposition of the entrepreneurial subjectivity of neoliberalism (Poulantzas 2000, p. 205, 24I):

Not only does authoritarian statism fail to enclose the masses in its disciplinary web or to 'integrate' them in its authoritarian circuits; it actually provokes ... a veritable explosion of democratic demands. (Poulantzas 2000, p. 247)

In recent years there have been increasing examples of such challenges to neoliberal orthodoxy. From the initial rise of Syriza in Greece, to the candidacy of Bernie Sanders and the Black Lives Matter movement in the United States, and the shift to the left by the Labour Party in the United Kingdom, it is no longer credible to assert that 'there is no alternative' to neoliberalism. While processes of subjectivation are important in the normalisation and internalisation of the mode of entrepreneurialism, it is also crucial to remain open to the possibilities of collective contestation of neoliberal ideas and their forceful dissemination through the exercise of state authority.

\footnotetext{
7 Boukalas suggests that authoritarian statism provides a more nuanced way of understanding such developments than Giorgio Agamben's depiction of a permanent state of exception.
} 
ACKNOWLEDGEMENT. I would like to dedicate this article to my father, Adrian Butler, who died in July 2018. He had personal experience of the introduction of 'new public management' techniques in the Queensland Public Service during the 1980s, and gave me my first insights into the role of the state in promoting and reinforcing neoliberalism. His critical perspective on politics and his wry humour will be sorely missed.

\section{REFERENCES}

Australian Council of Social Service (ACOSS). 2017. Submission to Senate Standing Committee on Community Affairs Inquiry into the Better Management of the Social Welfare System, 21 March 2017, available at: https://www.acoss.org.au/acossreports-submissions/, last accessed II September 2018

Bonefeld, Werner. 2010a. Freedom and the strong state: On German ordoliberalism, New Political Economy 17(5): 633-656.

Bonefeld, Werner. 20l0b. Free economy and the strong state: Some notes on the state, Capital \& Class 34(I): 15-24.

Bonefeld, Werner. 2017. Authoritarian liberalism: From Schmitt via ordoliberalism to the euro, Critical Sociology 43(4-5): 747-76I.

Boukalas Christos. 20I4. No exceptions: Authoritarian statism. Agamben, Poulantzas and homeland security, Critical Studies on Terrorism 7(I): II2-I30.

Brenner, Neil. 200I. State theory in the political conjuncture: Henri Lefebvre's 'Comments on a new state form', Antipode 33(5): 783-808.

Brenner Neil. 2004. New state spaces: Urban governance and the rescaling of statehood. Oxford: Oxford University Press.

Brown, David. 20I I. Neoliberalism as a criminological subject, Australian and New Zealand Journal of Criminology 44(I): I29-I42.

Brown, Wendy. 2003. Neo-liberalism and the end of liberal democracy, Theory \& Event 7(I): https://muse.jhu.edu/article/48659.

Brown, Wendy. 2006. American nightmare: Neoliberalism, neoconservatism and dedemocratization, Political Theory 34(6): 690-7/4.

Brown, Wendy. 2015. Undoing the demos: Neoliberalism's stealth revolution. New York: Zone Books.

Brown, Wendy. 2017. Apocalyptic populism, Eurozine, 30 August 2017, Available at: https://www.eurozine.com/apocalyptic-populism/.

Bruff, lan. 20 I4. The rise of authoritarian neoliberalism, Rethinking Marxism 26(I): I I3-I 29.

Bruff, lan. 2016. Neoliberalism and authoritarianism. In The handbook of neoliberalism, eds. Simon Springer, Kean Birch, and Julie MacLeavy. Abingdon: Routledge; I07-I I7.

Bruff, lan, and Cemal Burak Tansel. 2018. Authoritarian neoliberalism: Trajectories of knowledge production and praxis, Globalizations, DOI: 10.1080/14747731.2018.1502497.

Butler, Chris. 2012. Henri Lefebvre: Spatial politics, everyday life and the right to the city. Abingdon: Routledge.

Carney, Terry. 2018. The new digital future for welfare: Debts without legal proofs or moral authority? University of New South Wales Law Journal Forum March: I- 16.

Coglianese, Cary, and David Lehr. 2017. Regulating by robot: Administrative decision making in the machine-learning era, Georgetown Law Journal I05: II47-I 223.

Cristi, F.R. 1984. Hayek and Schmitt on the rule of law, Canadian Journal of Political Science 17(3): $521-535$.

Cristi, Renato. 1998. Carl Schmitt and authoritarian liberalism: Strong state, free economy. Cardiff: University of Wales Press. 
Davies, William. 2015. The chronic social: Relations of control within and without neoliberalism, New Formations 84/85: 40-57.

De Angelis, Massimo. 200I. Marx and primitive accumulation: The continuous character of capital's 'enclosures'. Available at: http://www.commoner.org.uk/?p=5.

Dean, Jodi. 2016. Neoliberalism's defeat of democracy: Review of Wendy Brown, Undoing the demos: Neoliberalism's stealth revolution, Critical Inquiry 42(4): 979-982.

Dean, Mitchell. 20I4. Rethinking neoliberalism, Journal of Sociology 50(2): I50-I63.

Delezue, Gilles. 197I. Nature des flux, Lecture at Vincennes, I4 December, Available at: https://www.webdeleuze.com/textes/I I8.

Deleuze, Gilles. 1992. Postscript on the societies of control, October 59: 3-7.

Deleuze, Gilles, and Felix Guattari. 1983. Anti Oedipus: Capitalism and schizophrenia, trans. Robert Hurley, Mark Seem, and Helen R. Lane. Minneapolis: University of Minnesota Press.

Demirović, Alex. 20II. Rule of the people? Democracy and the capitalist state in the work of Nicos Poulantzas. In Reading Poulantzas, eds. Alexander Gallas, et al. Pontypool: Merlin Press: 26I-276.

Desai, Deven, and Joshua Kroll. 2017. Trust but verify: A guide to algorithms and the law, Harvard Journal of Law \& Technology 3 I(I): I-64.

Fisher, Mark. 2009. Capitalist realism: Is there no alternative. Zero Books.

Fisher, Mark, and Jeremy Gilbert. 2013. Capitalist realism and neoliberal hegemony: A dialogue, New Formations 80-81: 89-101.

Foucault, Michel. 2008. The birth of biopolitics: Lectures at the Collège de France 1978-1979. Houndmills, Basingstoke: Palgrave Macmillan.

Galloway, Kate. 2017. Big Data: A case study of disruption and government power, Alternative Law Journal 42(2): 89-95.

Gamble, Andrew. 1994. The free economy and the strong state: The politics of Thatcherism. London: Macmillan.

Gane, Nicholas. 2016. Review: Wendy Brown, Undoing the demos: Neoliberalism's stealth revolution, Theory, Culture \& Society 37(7-8): 350-355.

Hall, Stuart. 1980. Popular democratic vs. authoritarian populism: Two ways of taking democracy seriously. In Marxism and democracy, ed. Alan Hunt. London: Lawrence and Wishart, 157-185.

Hall, Stuart. 1985. Authoritarian populism: A reply to Jessop et al, New Left Review I5I: I I5124.

Hall, Stuart, (et al). 1978. Policing the crisis: Mugging, the state and law and order. London: Macmillan.

Hanks, Peter. 2017. Administrative law and welfare rights: A 40-year story from Green v Daniels to robo-debt recovery, Australian Institute of Administrative Law Forum 89: I-I5.

Harvey, David. 2003. The new imperialism. Oxford: Oxford University Press.

Harvey, David. 2005. A brief history of neoliberalism. Oxford: Oxford University Press.

Harvey, David. 2006. Neo-liberalism as creative destruction, Geografiska Annaler 88B(2): I45I58:

Hayek, Friedrich. 1960. The constitution of liberty. Chicago: University of Chicago Press.

Hayek, Friedrich. 1966. The principles of a liberal social order, II Politico 3I (4): 60I-6I8.

Jessop, Bob. 1980. The capitalist state and political practice, Economy and Society 9(I): 108127.

Jessop, Bob. 20II. Poulantzas's State, Power, Socialism as a modern classic. In Reading Poulantzas, ed. Alexander Gallas, et al. Pontypool: Merlin Press: 4I-55. 
Kalyvas, Andreas. 2002. The stateless theory: Poulantzas's challenge to postmodernism. In Paradigm lost: State theory reconsidered, eds. Stanley Aronowitz and Peter Bratsis. Minneapolis: University of Minnesota Press: 105-I 42.

Lafargue, Paul. 20II. The right to be lazy. Edinburgh: AK Press.

Lazzarato, Maurizio. 2002. Puissances de l'invention: La psychologie économique de Gabriel Tarde contre l'économie politique. Paris: Les Empecheurs de Penser en Rond.

Lazzarato, Maurizio. 2004. Les revolutions du capitalisme. Paris: Les Empecheurs du Penser en Rond/Le Seuil.

Lazzarato, Maurizio. 2007. Machines to crystallize time: Bergson, Theory, Culture \& Society 24(6): 93-122.

Lazzarato, Maurizio. 2012. The making of the indebted man: An essay on the neoliberal condition, trans. Joshua David Jordan, Los Angeles: Semiotext(e).

Lazzarato, Maurizio. 2014. Marcel Duchamp and the refusal of work, trans. Joshua David Jordan. Los Angeles: Semiotext(e).

Lazzarato, Maurizio. 20I5a. Governing by debt, trans. Joshua David Jordan. South Pasadena: Semiotext(e)

Lazzarato, Maurizio. 20 I5b. Neoliberalism, the financial crisis and the end of the liberal state, Theory, Culture \& Society 32(7-8): 67-83.

Lazzarato, Maurizio. 2017. Experimental politics: Work, welfare, and creativity in the neoliberal age. ed. Jeremy Gilbert; trans. Arianna Bove, Jeremy Gilbert, Andrew Goffey, Mark Hayward, Jason Read and Alberto Toscano. Cambridge, Mass.: MIT Press.

Lefebvre, Henri. 1977. De l'État III: Le mode de production étatique. Paris: Union Generale d'Editions.

Lefebvre, Henri. 200I. Comments on a new state form, Antipode 33(5): 769-782.

Lefebvre, Henri. 2003. Space and the state. In State/space, ed. N. Brenner, et al. Oxford: Blackwell: 84-100.

McKinnon, Alex. 2017. Debt.Recovery. The Monthly, August; available at: https://www.themonthly.com.au/issue/2017/august/I501509600/alex-mckinnon/debtrecovery

McLoughlin, Daniel. 2017. Lazzarato on neoliberalism and the limits of governmentality. Paper presented at the symposium Forms of authority beyond the neoliberal state, Griffith Law School, Brisbane, 4-5 December.

Midnight Notes Collective. 1990. The new enclosures. Available at: http://www.commoner.org.uk/?p=5

Mirowski, Philip. 2009. Postface: Defining neoliberalism. In The road from Mont Pèlerin: The making of the neoliberal thought collective, eds. Philip Mirowski, and D. Plehwe. Cambridge, Mass.: Harvard University Press: 4I 7-456.

Morrison, Scott, and Mathias Cormann. 2016. Mid-year economic and fiscal outlook 2016-17, Statement, December 2016. Available at: https://budget.gov.au/2016I7/content/myefo/html/.

Muldoon, James. 2014. Lazzarato and the micro-politics of invention, Theory, Culture \& Society 3I(6): $57-76$.

Nietzsche, Friedrich. 2006. On the genealogy of morality, ed. Keith Ansell-Pearson, trans. Carol Diethe. Cambridge: Cambridge University Press.

Peck, Jamie. 20I0a. Constructions of neoliberal reason. Oxford: Oxford University Press

Peck, Jamie. 20 IOb. Zombie neoliberalism and the ambidextrous state, Theoretical Criminology 14(I): 104-II0.

Peck, Jamie and Adam Tickell. 2002. Neoliberalizing space, Antipode 34(3): 380-404.

Poulantzas, Nicos. 2000. State, power, socialism. London: Verso. 
Pugliese, Joseph. 2013. Technologies of extraterritorialisation, statist visuality and irregular migrants and refugees, Griffith Law Review 22(3): 57 I-597.

Read, Jason. 2009. A genealogy of homo-economicus: Neoliberalism and the production of subjectivity. Foucault Studies 6: 25-36.

Ryan, Matthew. 2017. Authoritarian neoliberalism: Crisis, the state, and the challenge of periodisation. MPhil Thesis, Department of Political Economy, Faculty of Arts and Social Sciences, University of Sydney.

Scheuerman, William. 1997. The unholy alliance of Carl Schmitt and Friedrich A. Hayek. Constellations 4(2): I72-188.

Schmitt, Carl. 2006. The nomos of the earth in the international law of the jus publicum europaeum, trans. G.L. Ulmen. New York: Telos Press Publishing.

Senate Community Affairs References Committee. 2017. Design, Scope, Cost-Benefit Analysis, Contracts Awarded and Implementation Associated with the Better Management of the Social Welfare System Initiative (2017), Parliament of Australia; available at: https://www.aph.gov.au/Parliamentary_Business/Committees/Senate/Community_Aff airs/SocialWelfareSystem/Report.

Tansel, Cemal Burak, ed. 2017. States of discipline: Authoritarian neoliberalism and the contested reproduction of capitalist order. London: Rowman \& Littlefield International.

Toscano, Alberto. 2007. Vital strategies: Maurizio Lazzarato and the metaphysics of contemporary capitalism, Theory, Culture \& Society 24(6): 7I-9I.

Toscano, Alberto. 2014. Alien mediations: Critical remarks on The Making of the Indebted Man. The New Reader, I. Available at: http://thenewreader.org//ssues/I/AlienMediations.

Thoburn, Nicholas. 2003. Deleuze, Marx and politics. London: Routledge.

Tronti, Mario. 1965. The strategy of refusal. Available at: https://libcom.org/library/strategyrefusal-mario-tronti.

Tronti, Mario. 1977. Sull'autonomia del politico. Milano: Feltrinelli.

Tzouvala, Ntina. 2017. Continuity and rupture in restraining the right to strike. In Neoliberal legality: Understanding the role of law in the neoliberal project, ed. Honor Brabazon. Abingdon: Routledge, I19-139.

Wacquant, Loïc. 2009. Punishing the poor: The neoliberal government of social insecurity. Durham: Duke University Press.

Wacquant, Loïc. 2010. Crafting the neoliberal state: Workfare, prisonfare, and social insecurity, Sociological Forum 25(2): 197-220.

Wacquant, Loïc. 20l4. The global firestorm of law and order: On punishment and neoliberalism, Thesis Eleven I22(I): 72-88. 